\title{
Pentingnya Kecerdasan Spiritual bagi Self-Regulated Learning Siswa SMA
}

\author{
Fifi Indrayani, Yuzarion, Nurul Hidayah \\ Universitas Ahmad Dahlan Yogyakarta
}

\begin{abstract}
Self-regulated learning is important for students for the optimal learning process and learning goals. This study aims to test empirically how spiritual intelligence predicts self-regulated learning in high school students in the city of North Maluku using linear regression techniques to 123 participants selected based on purposive random sampling, the measurement was carried out using 20 items on the spiritual intelligence scale (Cronbach $\alpha$ coefficient $=0.83$.) and 22 items on the scale of self-regulated learning $g$ (Cronbach's $\alpha$ coefficient $=0.96)$ The results of data analysis show that the regression coefficient $(t)$ is 15.422 with a significance level of $0.000(p<0.05)$, which means that spiritual intelligence can predict self-regulated learning for high school students with an effective contribution of $88.4 \%$. percent. Selfregulated learning is important for students for the optimal learning process and learning goals. This study aims to test empirically how spiritual intelligence predicts self-regulated learning in high school students in the city of North Maluku using linear regression techniques to 123 participants selected based on purposive random sampling, the measurement was carried out using 20 items on the spiritual intelligence scale (Cronbach $\alpha$ coefficient $=0.83$. ) and 22 items on the scale of self-regulated learning $g$ (Cronbach's $\alpha$ coefficient $=0.96$ ) The results of data analysis show that the regression coefficient $(t)$ is 15.422 with a significance level of $0.000(p<0.05)$, which means that spiritual intelligence can predict self-regulated learning for high school students with an effective contribution of $88.4 \%$. percent.
\end{abstract}

Keyword: High School Students; Self-Regulated Learning; Spiritual Intelligence

\begin{abstract}
Abstrak
Self-regulated learning penting bagi siswa untuk proses pembelajaran dan tujuan pembelajaran yang optimal. Penelitian ini bertujuan untuk menguji secara empiris bagaimana kecerdasan spiritual memprediksi self-regulated learning pada siswa SMA dikota Maluku Utara menggunakan teknik regresi linier terhadap 123 partisipan yang terpilih berdasarkan purposive random sampling pengukuran dilakukan menggunakan 20 aitem skala kecerdasan spiritual (koefisien $\alpha$ Cronbach = 0,83) dan 22 aitem skala self-regulated learning g (koefisien $\alpha$ Cronbach = $0,96)$ Hasil analisa data menunjukkan nilai koefisien regresi ( $t$ ) sebesar 15,422 dengan taraf signifikansi sebesar 0,000 ( $\mathrm{p}<0,05)$ yang berarti bahwa kecerdasan spiritual dapat memprediksi self-regulated learning bagi siswa SMA dengan sumbangan efektif sebesar $88,4 \%$. persen.
\end{abstract}

Kata Kunci : Siswa SMA; Self-Regulated Learning; Kecerdasan Spiritual 
Manusia adalah kemampuan untuk mengatur diri sendiri dalam Keterampilan meregulasi diri untuk memahami bagaimana kemampuan ini berkembang dalam pengaturan belajar pada diri sendiri, terutama bila menghadapi tugastugas yang sulit. Self-regulated learning menekankan pentingnya inisiatif, karena self-regulated learning merupakan proses belajar yang terjadi atas inisiatif. (Zimmerman, 2000)

Konsepsasi mengenai pembelajaran mandiri siswa mengarahkan dan mengatur proses pembelajaran untuk merencanakan kegiatan belajar, menetapkan tujuan, mencari, menulis dan mengembangkan sendiri materi baik yang telah dibahas maupun materi yang akan dibahas relevan dengan materi dikelas (Boekaerts, 1999). Penelitian ini bertujuan untuk melihat bagaimana self-regulated learning siswa dipengaruhi variabel lain, dalam hal ini yaitu kecerdasan spiritual. Model konseptual self-regulated learning yang dikemukakan oleh Zimmerman, 2013 melihat self regulated learning dari sudut pandang siswa yang terdiri dari tiga aspek yaitu metakognisi, motivasi, dan perilaku.

Studi pendahuluan peneliti pada siswa suatu SMA di Kota Maluku Utara menunjukan bahwa self-regulated learning pada siswa masih rendah. Hal tersebut dapat dilihat pada aspek metakognisi, siswa merasa kurang mengatur sendiri penetapan tujuan belajar , akibat tidak bisa mandiri dalam belajar; atau aspek motivasi, misalnya, ada siswa yang tidak minat pada mata pelajaran yang diberikan oleh guru dikelas ; serta dalam aspek perilaku, bahwa siswa tidak mengoptimalkan pembelajaran disekolah maupun dirumah,sulit mencari informasi dalam pembelajaran. Kondisi tersebut menunjukan bahwa masih belum tercapai adanya kemandirian belajar (self-regulated learning) yang ditandai dengan rasa tidak memiliki kemandirian belajar dalam proses pembelajaran, , serta kualitas kehidupan di sekolah yang kurang baik pada SMA di Kota Maluku Utara.

Hal ini membuktikan bahwa self-regulated learning siswa di SMA masih tergolong rendah, karena siswa belum mampu untuk melakukan regulasi diri yang baik dalam belajar sehingga menyebabkan siswa tidak bisa mengatur jadwal belajar, tidak mau mengerjakan tugas dan tidak punya keinginan untuk mencapai prestasi belajar yang lebih baik. Selain itu siswa memiliki kemampuan dalam Pembelajaran mandiri untuk membangun pengetahuan dalam perubahan untuk menngkatkan prestasi akademik pada siswa (Winne, 2005) 
Berdasarkan hasil studi dilapangan yang dilakukan oleh Alhadi et al., 2017, mengemukakan bahwa dapat mendorong siswa untuk mengembangkan kemampuan mengatur diri dalam belajar secara optimal. Konsep pembelajaran mandiri pada siswa yang dapat mengatur penetapan tujuan dan perencanaan, minat tugas (Dabbagh \& Kitsantas, 2012).

Program self-regulated learning menjadi penting dan bermanfaat jika diterapkan di sekolah, karena siswa dapat belajar secara efektif dengan strategi dan tujuan belajar yang optimal. Suatu studi mengungkapkan bahwa Siswa dengan selfregulated learning dalam proses pembelajarannya dapat memberikan dampak yang kuat terhadap kesadaran proses pembelajaran, pengetahuan, kepercayaan, dan pendapat tentang pembelajaran dan beberapa hal yang berdampak pada proses pembelajaran (Ferla, 2008). Berbagai temuan ini menunjukkan bahwa sangat penting untuk mengelola self regulated learning pada siswa.

Hasil studi pendahuluan pada 20 siswa Sekolah Menegah Atas (SMA) Halmahera Tengah menunjukan bahwa 6 siswa memiliki self-regulated learning pada tingkat yang sangat tinggi, 9 siswa memiliki self-regulated learning yang tinggi, 2 siswa memiliki self-regulated learning yang sedang, dan 3 siswa memiliki self-regulated learning yang rendah. Hal tersebut menunjukan bahwa tidak semua siswa memiliki self-regulated learning yang tinggi. Taraf selfregulated learning yang berbeda dari setiap individu, berdasarkan pemaparan sebelumnya, artikel ini bertujuan untuk menjawab pertanyaan, apakah kecerdasan spiritual dapat memprediksi self-regulated learning siswa SMA di Kabupaten Halmahera Tengah? Pertanyaan tersebut akan dijawab dengan hipotesis peneliti, yakni terdapat hubungan positif kecerdasan spiritual dengan self-regulated learning siswa SMA di Kota Maluku Utara, yang berarti semakin tinggi kecerdasan spiritual maka semakin tinggi pula self-regulated learning, begitu pula sebaliknya, sehingga dapat dinyatakan bahwa kecerdasan spiritual dapat memprediksi selfregulated learning siswa SMA di Kabupaten Halmahera Tengah . 
Perkembangan self-regulated learning pada siswa sangat ditentukan oleh faktor personal terhadap dirinya. Faktor personal terhadap dirinya disebut sebagai kecerdasan spiritual adalah kesadaran sebagai kemampuan untuk menyadari proses mental dan struktur (G. et al., 2011)

Individu yang memiliki kecerdasan spiritual mampu merialisasi makna yang dimiliki individu kehidupan batin pikiran dan roh yang berhubungan langsung dengan keberadaan dunia, pemahaman tentang eksistensi, memiliki kesadaran sebagai kekuatan dalam kehidupan yang kreatif, tingkat perkembangan kognitif, emosional, dan interpersonal (Vaughan, 2002).

Di antara konsep dasar dari kecerdasan spiritual adalah kemampuan untuk menyadari proses mental dan struktur kesadaran. Teori kecerdasan spiritual mengacu pada kemampuan untuk mengakses, mengekspresikan dan memproses informasi spiritual. Spiritualitas dapat dikonseptualisasikan dalam istilah kognitif-motivasi (Salen et al., 2006) . Kecerdasan spiritual adalah sebagai bakat mental yang digunakan oleh manusia untuk diatasi dan ditemukan solusi untuk masalah makna dan nilai dalam hidup (Adams \& Hyde, 2008). Penerapan kecerdasan spiritual dapat membantu individu dalam memecahkan masalah makna, kehidupan duniawi dan akhirat meliputi visi hidup dan bukan hanya tujuan dari hidup, menyangkut keseluruhan hidup bahkan keseluruhan alam semesta, sehingga dibutuhkan kesadaran diri dan penerungan yang mendalam untuk memahami kecerdasan spiritual (Emmons, 2000).

\section{Metode}

Metode yang digunakan dalam penelitian ini adalah penelitian kuantitatif noneksperimen program SPSS 22.0 for windows evaluation version. Jumlah populasi seluruhnya berjumlah 150 siswa yang terdiri dari kelas 75 siswa kelas XI IPS dan 75 siswa kelas XI IPA. Sampel penelitian berjumlah 100 siswa yang dipilih secara purposive random sampling yang terdiri dari 50 siswa kelas XI IPS dan 50 siswa kelas XI IPS kedua sekolah ada di kota Maluku Utara Variabel penelitian meliputi variabel bebas $(\mathrm{X})$ dan variabel terikat $(\mathrm{Y})$. Variabel bebas $(\mathrm{X})$ yakni kecerdasan spiritual dan variabel terikat (Y) yakni self-regulated learning. Pengambilan data penelitian menggunakan alat ukur berupa skala Likert yang terdiri atas skala pengukuran 
masing-masing variabel menggunakan 20 aitem skala kecerdasan spiritual disusun peneliti berdasarkan aspek kecerdasan spiritual yang dikemukakan oleh David king (2008) dan 22 aitem skala self-regulated learning disusun peneliti berdasarkan aspek self-regulated learning yang dikemukakan oleh Zimmerman (2013). Reliabilitas masing-masing skala adalah reliabel dengan nilai koefisien $\alpha$ Cronbach sebesar 0,83 (skala kecerdasan spritual) dan 0,96 (skala self-regulated learning). Analisis data penelitian menggunakan dua uji yaitu uji asumsi penelitian dan uji hipotesis penelitian. Uji asumsi penelitian terdiri dari uji normalitas dengan kolmogrovsmirnov. Uji linieritas dengan Compare Mean, dan uji multikulniaritas. Uji hipotesis.

Sebelum skala disebar kepada sampel penelitian, peneliti melakukan uji coba alat ukur kepada 50 siswa yang berusia 15 tahun sampai 18 tahun dan menempuh pendidikan dikelas XI pada sekolah menengah atas Negeri 1 Halmahera Tengah. Kemudian peneliti melakukan analisis validitas dan reliabilitas skala. Hasil Validitas aitem-aitem valid pada skala kecerdasan spiritual berkisar antara 0,300 sampai 0,637, skala kecerdasan spiritual sekitar 0,300 sampai 0,637 dan skala self-regulated learning berkisar antara 0,338 sampai 0,626. Hasil uji reliabilitas masing-masing skala menggunakan cronbach alpha yaitu skala spiritual alpha sebesar 0,872 >0,7 dengan jumlah aitem sebanyak 20 dan skala self-regulated learning 0,885 > 0,7 dengan jumlah aitem sebanyak 22 .

\section{Hasil}

Hasil analisa deskriptif menunjukkan kategorisasi subjek penelitian pada masingmasing variabel yakni sebagaimana tersaji pada tabel. 1 berikut.

Tabel 1

Kategorisasi Subjek Berdasarkan Variabel

\begin{tabular}{cccc}
\hline Variabel & Kategorisasi(dalam persen) & & \\
\cline { 2 - 2 } & Rendah & Tinggi & Sedang \\
\hline $\begin{array}{c}\text { Kecerdasan } \\
\text { Spiritual }\end{array}$ & $21 \%$ & $20 \%$ & $59 \%$ \\
$\begin{array}{c}\text { Self-regulated } \\
\text { Learning }\end{array}$ & $17 \%$ & $20 \%$ & $63 \%$ \\
\hline
\end{tabular}


Berdasarkan deskripsi subjek penelitian pada self-regulated learning diketahui bahwa mayoritas subjek yang berpartisipasi dalam penelitian ini adalah 20 siswa yang masuk dalam kategori tinggi atau sebesar 20\%, 63 siswa yang masuk dalam kategori sedang atau sebesar 63\%, 17 siswa yang masuk dalam kategori rendah atau sebesar $17 \%$.

Tabel 2 menjelaskan tentang deskripsi statistik data penelitian yang dihitung dengan membandingkan rerata empiris dengan rerata teoretis untuk melihat kategori secara umum pada masing-masing variabel

Tabel 2

Hasil uji linearitas data penelitian

\begin{tabular}{cccc}
\hline Variabel & Linearity & $\begin{array}{c}\text { Deviation from } \\
\text { Linearity }\end{array}$ & Kesimpulan \\
\hline $\begin{array}{c}\text { Self-regulated Learning* } \\
\text { Kecerdasan Spiritual }\end{array}$ & 0,000 & 0,359 & Data Linear \\
\end{tabular}

Berdasarkan tabel 2, hasil uji regresi linier menunjukkan bahwa kecerdasan spiritual dapat memprediksi self-regulated learning. Berdasarkan hasil perhitungan diketahui bahwa nilai t sebesar 15,422 dengan taraf signifikansi (nilai p) sebesar 0,000 ( $\mathrm{p}<0,05)$, maka dinyatakan signifikan, yang berate kecerdasan spiritual dapat memprediksi self-regulated learning secara signifikan. Hipotesis yang diajukan teruji kebenarannya, data yang diperoleh menunjukan kecerdasan spiritual dapat memprediksi self regulated learning. Sumbangan efektif variabel kecerdasan spiritual terhadap self regulated learning dihitung menurut rumus $S E=\beta \times$ zero $x$ 100 persen, dan didapat sebesar 5,17 persen dengan taraf signifikansi $\mathrm{F}$ 0,000 > 0,05, maka dinyatakan signifikan.

\section{Pembahasan}

Siswa disekolah Menengah Atas di Halmahera Tengah mampu mengembangkan selfregulated learning karena terdapat peran yang signifikan dari kecerdasan spiritual, sehingga hipotesis mayor pada penelitian ini dapat diterima. Peran self-regulated learning dengan 
kecerdasan spiritual berdasarkan nilai sig F 0,000 > 0,05 menunjukan hasil yang siginifikan. Diketahui adanya pengaruh antara kecerdasan spiritual dengan self regulated learning secara simultan dengan sumbangan efektif sebesar 93,8\% maka semakin tinggi kecerdasan spiritual maka akan tinggi juga self regulated learning. Hasil Lainnya menunjukan ada peranan kecerdasan spiritual terhadap self regulated learning, sehingga kecerdasan spiritual perlu dipertahankan untuk mengembangkan potensi siswa dalam optimalisasi proses belajar (Husna et al., n.d.)

Individu memiliki kecerdasan spiritual kemampuan dalam jiwa seseorang untuk membangun diri secara utuh melalui berbagai kegiatan positif sehingga mampu menyelesaikan masalah dan menghadapi tantangan melalui makna yang terkandung di dalamnya, karena kesuksesan peserta didik juga dipengaruhi oleh kecerdasan spiritual (Sulastyaningrum, Martono,.., \& Wahyono, 2019). Berdasarkan hasil analisis yang dilakukan oleh Alkautzar, 2018 menunjukan bahwa kecerdasan spiritual memiliki kontribusi yang signifikan dengan selfregulated learning. Karakteristik seseorang yang kecerdasan spiritualnya telah berkembang dengan baik adalah seseorang yang memiliki kemampuan (Zohar, 2002).

Kecerdasan spiritual pada penelitian ini tergolong tinggi. Tingginya taraf kecerdasan spiritual pada siswa Sekolah Menengah Atas di Kabupaten Halmahera Barat dapat dikaitkan dengan proses kegiatan belajar mengajar disekolah. Berdasarkan hasil studi pendahuluan, diketahui bahwa sekolah di Kabupaten Halmahera Tengah sdah banyak menerapan sistem dengan baik. Rasa kesadaran yang tinggi, dapat mengembangkan sifat konstruktif kemampuan untuk menghadapi kemarahan pada seseorang.Individu dengan kecerdasan spiritual yang tinggi lebih banyak jujur dan penuh kasih sayang terhadaap sesama dalam hidupnya (Samul, 2020).Siswi-siswi dibiasakan untuk melakukan kegiatan pembelajaran, membentuk kelompok belajar, untuk mengerjakan tugas dan guru melatih siswa untuk mengajukan pertanyaan. Ketika siswa mendapatkan timbal balik positif pada pembelajaran. (Samul, 2020)

\section{Kesimpulan}

Berdasarkan hasil penelitian dan pembahasan dapat disimpulkan bahwa kecerdasan spiritual dapat memprediksi self regulated learning. Hasil tersebut membuktikan bahwa 
semakin tinggi kecerdasan spiritual maka ada kecenderungan peningkatan self-regulated learning siswa Sekolah Menengah Atas Kabupaten Halmahera Tengah, dan kecerdasan spiritual merupakan variabel penting yang dapat menentukan self regulated learning Sekolah Menengah Atas di Kabupaten Halmahera Tengah tergolong tinggi.

Saran

Bagi siswa Pentingnya kecerdasan spiritual, dengan self-regulated learning bagi anak didik ataupun siswa terutama dalam meningkatkan self-regulated learning, diharapkan pihak sekolah untuk lebih mengintensifkan pembelajaran tentang mengembangkan dirinya untuk menciptakan nilai-nilai positif, mengembangkan emosi dan mengelola dalam belajar serta kemandirian dalam belejar pada siswa

Saran bagi peneliti selanjutnya yaitu diharapkan menggunakan subjek penelitian yang lebih besar agar data yang diperoleh dapat lebih representatif dan bervariasi. Peniliti selanjutnya diharapkan mampu meneliti variabel bebas lainnya yang mungkin berperan terhadap self-regulated learning agar lebih baik menggunakan alat ukur penelitian yang konsisten meneliti variabel diantaranya tipe kepribadian

\section{Referensi}

Adams, K., \& Hyde, B. (2008). Children's Grief Dreams and the Theory of Spiritual Intelligence. Dreaming, 18(1), 58-67.

Alhadi, S., Supriyanto, A., Learning, S., \& Pendahuluan, A. (2017). Self-Regulated Learning Concept : $333-342$.

Alkautzar, A. M. A. (2018). Hubungan Kecerdasan Emosional, Kecerdasan Spiritual dan Regulasi Diri Dalam Belajar (Self-Regulated Learning) Terhadap Hasil Ujian Osca Mahasiswa Kebidanan Stikes Mega Rezky Makassar. Journal of islamic nursing, 3(1), 919.

Boekaerts, M. (1999). Self-Regulated Learning: Where We Are Today. International Journal of Educational Research, 31(6), 445-457.

Dabbagh, N., \& Kitsantas, A. (2012). Personal Learning Environments, Social Media, And SelfRegulated Learning: A Natural Formula For Connecting Formal And Informal Learning. Internet and Higher Education, 15(1), 3-8.

Emmons, R. A. (2000). Is Spirituality An Intelligence? Motivation, Cognition, And The Psychology Of Ultimate Concern. International Journal of Phytoremediation, 21(1), 3-26.

Ferla, J. (2008). The Effects Of Student Cognitions About Learning On Self-Regulated Learning: A Study With Freshmen In Higher Education Proefschrift Ingediend Tot Het 
Behalen Van De Academische Graad Van Doctor In De Pedagogische Wetenschappen. Dissertation, De Pedagogische Wetenschappen, 206.

Fredricks, J. A., Blumenfeld, P. C., \& Paris, A. H. (2004). School Engagement Potential of The Concept. Review of Educational Research, 74(1), 59-109.

G., H., J., S., \& B., B. (2011). International Journal for the Psychology of Religion. Journal of Psychology and Theology, 39(2), 167.

Husna, T. A., Mayangsari, M. D., Rachmah, D. N., Psikologi, P. S., Kedokteran, F., Mangkurat, U. L., Km, J. A. Y., \& Selatan, B. K. (n.d.). Peranan Kecerdasan Spiritual Terhadap Regulasi Diri Martapura The Role Of Spiritual Intelligence Towards Self-Regulation In Learning In Female Students At Islamic Junior High School Darul Hijrah Puteri.

Murphy, P. K., \& Alexander, P. A. (2000). A Motivated Exploration Of Motivation Terminology. Contemporary Educational Psychology, 25(1), 3-53. https://doi.org/10.1006/ceps.1999.1019

Salen, G., Starc, T., Sisk, C. M. C., \& Patel, S. B. (2006). Intestinal Cholesterol Absorption Inhibitor Ezetimibe Added to Cholestyramine for Sitosterolemia and Xanthomatosis. Gastroenterology, 130(6), 1853-1857.

Samul, J. (2020). Emotional And Spiritual Intelligence Of Future Leaders: Challenges For Education. Education Sciences, 10(7), 1-10.

Sulastyaningrum, R., Martono, T., \& Wahyono, B. (2019). Pengaruh Kecerdasan Intelektual, Kecerdasan Emosional, Dan Kecerdasan Spiritual Terhadap Prestasi Belajar Mata Pelajaran Ekonomi Pada Peserta Didik Kelas XI IPS Di SMA Negeri 1 Bulu Tahun Ajaran 2017/2018. Jurnal Pendidikan Bisnis dan Ekonomi, 4(2).

Vaughan, F. (2002). What Is Spiritual Intelligence? Journal of Humanistic Psychology, 42(2), 1633.

Winne, P. H. (2005). A Perspective On State-Of-The-Art Research On Self-Regulated Learning. Instructional Science, 33(5-6), 559-565.

Zimmerman, B. J. (2013). From Cognitive Modeling to Self-Regulation: A Social Cognitive Career Path. Educational Psychologist, 48(3), 135-147.

Zimmerman, B. J. (2000). Chapter 2: Attening Self-Regulation A Social Cognitive Perspective. Handbook of Self-Regulation, 13-39.

Zohar, D. (2002). SQ : Memanfaatkan Kecerdasan Spiritual Dalam Berpikir Integralistik Danholistik Untuk Memaknai Kehidupan / Danah Zohar dan Ian Marshall.

Zohar, D., \& Marshall, I. (2000). Spirituelle Intelligenz. Die notwendige Frage nach dem Sinn, Bern, 02-187.

\begin{tabular}{|l|l|l|l|l|}
\hline Submit & Review & Revisi & Diterima & Publis \\
\hline 07-04-2021 & 07-04-2021 sd 14-04-2021 & $30-04-2021$ & $02-05-2021$ & $08-06-2021$ \\
\hline
\end{tabular}

Fifi Indrayani, Yuzarion, Nurul Hidayah Universitas Ahmad Dahlan, Yogyakarta Email : fifiabdwahab94@gmail.com 